DOI: $10.19195 / 0137-1134.106 .19$

PAWEŁ KŁUSEK

Uniwersytet Wrocławski

\title{
OGRANICZENIE DZIAŁALNOŚCI TELEKOMUNIKACYJNEJ W STANIE WOJENNYM I STANIE WYJĄTKOWYM
}

\section{WSTĘP}

Działalność telekomunikacyjna jest szczególnym rodzajem aktywności gospodarczej, która może być wykonywana przez prywatnych przedsiębiorców i jednostki samorządu terytorialnego. Obecnie możemy zaobserwować wzrost znaczenia usług telekomunikacyjnych, a zwłaszcza usług polegających na zapewnieniu szerokopasmowego dostępu do internetu. Ich świadczenie zaspokaja potrzeby społeczeństwa, które współcześnie możemy uznać za podstawowe do jego prawidłowego funkcjonowania.

Jednocześnie należy pamiętać, że każda działalność, w tym także działalność telekomunikacyjna, może zostać ograniczona w szczególnych przypadkach, jak wprowadzenie stanów nadzwyczajnych, o których mowa w rozdziale XI Konstytucji RP. Ustawa zasadnicza zalicza do nich: stan wojenny, stan wyjątkowy i stan klęski żywiołowej. W każdym z nich dopuszczalne są pewne ograniczenia niektórych konstytucyjnych praw i wolności, przy czym w stanie wojennym i stanie wyjątkowym regulacje te są bardzo podobne.

Celem niniejszego artykułu będzie ustalenie zakresu dopuszczalnych ograniczeń działalności telekomunikacyjnej w ustawie o stanie wojennym oraz kompetencjach Naczelnego Dowódcy Sił Zbrojnych i zasadach jego podległości konstytucyjnym organom Rzeczypospolitej Polskiej i w ustawie o stanie wyjątkowym.

\section{DZIAŁALNOŚĆ TELEKOMUNIKACYJNA I PODMIOTY JĄ WYKONUJĄCE}

\subsection{RODZAJE DZIAŁALNOŚCI TELEKOMUNIKACYJNEJ}

Najważniejsze akty normujące kwestie związane z prowadzeniem działalności telekomunikacyjnej to ustawa z dnia 16 lipca 2004 r. Prawo telekomunikacyj- 
ne $^{1}$ i ustawa z dnia 7 maja 2010 r. o wspieraniu rozwoju usług i sieci telekomunikacyjnych ${ }^{2}$. Obydwie ustawy definiują pojęcie działalności telekomunikacyjnej, regulując odmiennie jej zakres.

Zgodnie $\mathrm{z}$ art. 1 ust. 1 pkt 1 PrTel działalność telekomunikacyjna polega na świadczeniu usług telekomunikacyjnych, świadczeniu usług towarzyszących i dostarczaniu sieci telekomunikacyjnych. Wymienione rodzaje działalności telekomunikacyjnej zostały opisane w słowniczku ustawowym znajdującym się w art. 2 PrTel.

Pierwszym rodzajem takiej działalności jest świadczenie usług telekomunikacyjnych, zdefiniowane w art. 2 pkt 41 PrTel jako ,wykonywanie usług za pomocą własnej sieci, z wykorzystaniem sieci innego operatora lub sprzedaż we własnym imieniu i na własny rachunek usługi telekomunikacyjnej wykonywanej przez innego dostawcę usług". Natomiast samo pojęcie usługi telekomunikacyjnej, zgodnie z art. 2 pkt 48 PrTel, należy rozumieć jako usługę polegającą głównie na przekazywaniu sygnałów w sieci telekomunikacyjnej.

Drugim rodzajem działalności telekomunikacyjnej jest świadczenie usług towarzyszących, których definicja znajduje się w art. 2 pkt 44a PrTel. W myśl tego przepisu za usługi towarzyszące uznaje się

usługi związane z siecią lub usługami telekomunikacyjnymi, które umożliwiają lub wspierają dostarczanie usług za pośrednictwem tych sieci lub usług lub które mogą służyć do tego celu i obejmują między innymi systemy translacji numerów lub systemy o równoważnych funkcjach, systemy dostępu warunkowego i elektroniczne przewodniki po programach, jak również inne usługi, takie jak usługi identyfikacji, lokalizacji oraz sygnalizowania obecności.

Należy podkreślić, że katalog usług towarzyszących zawarty w cytowanym przepisie ma charakter otwarty.

Trzecim rodzajem działalności, o której mowa w art. 1 ust. 1 pkt 1 PrTel, jest dostarczanie sieci telekomunikacyjnych, zdefiniowane w art. 2 pkt 4 PrTel. Stanowi on, że jest to „przygotowanie sieci telekomunikacyjnej w sposób umożliwiający świadczenie w niej usług, jej eksploatację, nadzór nad nią lub umożliwianie dostępu telekomunikacyjnego".

Wymienione rodzaje działalności telekomunikacyjnej należy interpretować przy jednoczesnym odwołaniu się do pojęcia telekomunikacji, które zostało objaśnione w art. 2 pkt 42 PrTel. Przepis ten stanowi, że telekomunikacją jest ,nadawanie, odbiór lub transmisja informacji, niezależnie od ich rodzaju, za pomocą przewodów, fal radiowych bądź optycznych lub innych środków wykorzystujących energię elektromagnetyczną". Przytoczona definicja może okazać się przydatna, jeżeli pojawią się wątpliwości odnośnie do przedmiotowego stosowania Prawa telekomunikacyjnego ${ }^{3}$.

1 Tekst jedn. Dz.U. z 2014 r., poz. 243 (dalej: PrTel).

2 Dz.U. z 2015 r., poz. 880 (dalej: WspRozwTelU).

3 S. Piątek, Prawo telekomunikacyjne. Komentarz, Warszawa 2013, s. 7. 
Szerszy zakres działalności telekomunikacyjnej przewiduje ustawa o wspieraniu rozwoju usług i sieci telekomunikacyjnych, regulująca wykonywanie takiej działalności przez jednostki samorządu terytorialnego. W art. 3 ust. 1 WspRozwTelU do działalności telekomunikacyjnej zalicza się: 1) budowę lub eksploatację infrastruktury telekomunikacyjnej i sieci telekomunikacyjnych oraz nabywanie prawa do tego typu infrastruktury i sieci; 2) dostarczanie sieci telekomunikacyjnych lub zapewnianie dostępu do infrastruktury telekomunikacyjnej; 3) świadczenie usług (z wykorzystaniem posiadanej infrastruktury telekomunikacyjnej i sieci telekomunikacyjnych) na rzecz: a) przedsiębiorców telekomunikacyjnych, b) podmiotów wymienionych w art. 4 pkt 1, 2, 4, 5 i 8 PrTel, c) a w określonym zakresie i po spełnieniu pewnych warunków także na rzecz użytkowników końcowych. Wymienione formy aktywności z zakresu telekomunikacji tylko częściowo pokrywają się z definicją ustanowioną w art. 1 ust. 1 pkt 1 PrTel.

Rodzaje działalności telekomunikacyjnej, które nie pokrywają się z zakresem działalności unormowanej w art. 1 ust. 1 pkt 1 PrTel, to budowanie infrastruktury telekomunikacyjnej i sieci telekomunikacyjnych, a także nabywanie prawa do infrastruktury telekomunikacyjnej i sieci telekomunikacyjnych ${ }^{4}$. Przede wszystkim należy odpowiedzieć na pytanie, czym są infrastruktura i sieci telekomunikacyjne. W tym celu trzeba się odwołać do przepisów Prawa telekomunikacyjnego, co umożliwia odesłanie zawarte w art. 2 ust. 2 WspRozwTelU ${ }^{5}$.

Otwarty katalog elementów zaliczanych do infrastruktury telekomunikacyjnej zawiera art. 2 pkt 8 PrTel. Stanowi on, że są to ,urządzenia telekomunikacyjne, oprócz telekomunikacyjnych urządzeń końcowych, oraz w szczególności linie, kanalizacje kablowe, słupy, wieże, maszty, kable, przewody oraz osprzęt, wykorzystywane do zapewnienia telekomunikacji”. Natomiast „sieć telekomunikacyjna" została zdefiniowana w art. 2 pkt 35 PrTel. Zaliczono do niej systemy transmisyjne, urządzenia komutacyjne lub przekierowujące, a także inne urządzenia (zasoby) - nawet te nieaktywne - które umożliwiają nadawanie, odbiór lub transmisję sygnałów. Przekazywanie tych sygnałów odbywa się za pomocą przewodów, fal radiowych, optycznych lub innych środków, które wykorzystują energię elektromagnetyczną, niezależnie od ich rodzaju.

Działalność telekomunikacyjna określona w art. 3 ust. 1 pkt 1 WspRozwTelU, niebędąca działalnością, o której mowa w art. 1 ust. 1 pkt 1 PrTel, polega na budowaniu i nabywaniu prawa do infrastruktury telekomunikacyjnej i sieci telekomunikacyjnych. W celu ustalenia, na czym polega budowanie infrastruktury lub sieci telekomunikacyjnych, musimy sięgnąć do przepisów ustawy z dnia 7 lipca 1997 r.

4 T. Grossmann et al., Ustawa o wspieraniu rozwoju ustug i sieci telekomunikacyjnych. Komentarz, Warszawa 2012, s. 65.

5 Art. 2 ust. 2 WspRozwTelU „Ilekroć w ustawie są używane określenia zdefiniowane w ustawie z dnia 16 lipca 2004 r. - Prawo telekomunikacyjne (Dz.U. z 2014 r., poz. 243, 827 i 1198), określenia te należy rozumieć w znaczeniu tam przyjętym". 
Prawo budowlane ${ }^{6}$. Zgodnie z art. 3 pkt 3 tej ustawy przez budowę należy rozumieć wykonanie obiektu budowlanego, a także jego odbudowę, rozbudowę lub nadbudowę. W definicji tej kluczowe jest pojęcie obiektu budowlanego, do którego zaliczają się między innymi infrastruktura i sieci telekomunikacyjne (art. 2 pkt 8 i 35 PrTel w zw. z art. 3 pkt 1 i 3 PrBud). Drugim rodzajem działalności wymienionym w art. 3 ust. 1 pkt $1 \mathrm{WspRozwTelU}$ jest ,nabywanie praw”. Mimo że ustawodawca nie wymienił, jakie prawa mogą być przedmiotem nabycia, należy przyjąć, że chodzi tu o prawo własności, ograniczone prawa rzeczowe, a także prawa obligacyjne ${ }^{7}$.

\subsection{DZIAŁALNOŚĆ TELEKOMUNIKACYJNA W SFERZE UŻYTECZNOŚCI PUBLICZNEJ}

Działalność telekomunikacyjna może być wykonywana w dwóch sferach jako działalność ze sfery użyteczności publicznej i jako zwykła działalność gospodarcza (działalność komercyjna). Działalność telekomunikacyjna w sferze użyteczności publicznej może być wykonywana przez wszystkie jednostki samorządu terytorialnego, $\mathrm{w}$ formach określonych $\mathrm{w}$ art. $5 \mathrm{WspRozwTelU}$. Natomiast komercyjną działalność telekomunikacyjną mogą wykonywać zarówno przedsiębiorcy, jak i samorząd wojewódzki.

Zgodnie z art. 1 ust. 2 GospKomU ${ }^{8}$ „Gospodarka komunalna obejmuje w szczególności zadania o charakterze użyteczności publicznej, których celem jest bieżące i nieprzerwane zaspokajanie zbiorowych potrzeb ludności w drodze świadczenia usług powszechnie dostępnych". Przepis ten określa konstytutywne cechy działalności ze sfery użyteczności publicznej, wykonywanej przez jednostki samorządu terytorialnego. Pierwszą z tych cech jest wykonywanie działalności w sposób stały, co wyklucza jej zawieszenie czy zaprzestanie, nawet gdy jest ona nierentowna ${ }^{9}$. Drugą cechą jest zaspokajanie potrzeb nieograniczonej liczby osób zamieszkujących dany region, a nie potrzeb indywidualnego mieszkańca ${ }^{10}$. Trzecią cechą jest sposób zaspokajania tych potrzeb, polegający na świadczeniu usług powszechnie dostępnych, co oznacza, że każdy mieszkaniec powinien mieć możliwość skorzystania z takiej usługi ${ }^{11}$. Warto też zaznaczyć, że działalność ze sfery użyteczności publicznej może polegać nie tylko na bezpośrednim świadczeniu określonych usług, lecz także na ich organizacji ${ }^{12}$. Podsumowując, należy

${ }^{6}$ Ustawa z dnia 7 lipca 1997 r. Prawo budowlane, Dz.U. z 2016 r., poz. 290.

7 T. Grossmann et al., op. cit., s. 23.

8 Ustawa z dnia 20 grudnia 1996 r. o gospodarce komunalnej, tekst jedn. Dz.U. z 2016, poz. 573.

9 W. Gonet, Ustawa o gospodarce komunalnej. Komentarz. Wzory umów i regulaminów, Warszawa 2010, s. 15.

10 S. Dudzik, Działalność gospodarcza samorzadu terytorialnego, Kraków 1998, s. 85.

11 J. Zięty, Ustawa o gospodarce komunalnej. Komentarz, Warszawa 2012, s. 16.

12 M. Szydło, Ustawa o gospodarce komunalnej. Komentarz, Warszawa 2008, s. 135. 
stwierdzić, że działalność telekomunikacyjna samorządu terytorialnego w sferze użyteczności publicznej powinna mieć wszystkie wymienione cechy.

Ważną kwestią jest także zakres działalności telekomunikacyjnej, jaka może być wykonywana $w$ ramach działalności ze sfery użyteczności publicznej. Rodzaje tej działalności zostały wymienione we wspomnianym już art. 3 ust. 1 WspRozwTelU, który zalicza do niej budowę, eksploatację i nabywanie praw do infrastruktury i sieci telekomunikacyjnych; dostarczanie sieci telekomunikacyjnych lub zapewnianie dostępu do infrastruktury telekomunikacyjnej oraz świadczenie usług, z wykorzystaniem posiadanej infrastruktury i sieci telekomunikacyjnych, na rzecz określonych podmiotów ${ }^{13}$. O charakterze tej działalności przesądza art. 3 ust. 4 WspRozwTelU, stanowiąc, że należy ona do „zadań własnych o charakterze użyteczności publicznej jednostki samorządu terytorialnego".

\subsection{KOMERCYJNA DZIAŁALNOŚĆ TELEKOMUNIKACYJNA}

Działalność telekomunikacyjna może być też prowadzona jako działalność gospodarcza w rozumieniu art. 2 SwobDziałU ${ }^{14}$. Przepis ten stanowi, że działalnością gospodarczą jest zarobkowa działalność wytwórcza, budowlana, handlowa, usługowa oraz poszukiwanie, rozpoznawanie, wydobywanie kopalin ze złóż, a także działalność zawodowa, wykonywana w sposób zorganizowany i ciągły. Najważniejszą cechą takiej działalności, która odróżnia ją od gospodarki komunalnej w sferze użyteczności publicznej, jest jej zarobkowy charakter. Przy czym zarobkowość należy tu rozumieć jako chęć osiągnięcia zysku ${ }^{15}$.

Jak już wspomniano, komercyjna działalność telekomunikacyjna może być wykonywana zarówno przez przedsiębiorców, jak i samorząd wojewódzki. Wynika to z treści art. 2 pkt 27 PrTel, który definiuje pojęcie przedsiębiorcy telekomunikacyjnego. Ustawodawca rozumie pod tym pojęciem przedsiębiorcę lub inny podmiot uprawniony do wykonywania działalności gospodarczej, polegającej na dostarczaniu sieci telekomunikacyjnych, świadczeniu usług towarzyszących lub świadczeniu usług telekomunikacyjnych. Wynika z tego, że przedsiębiorcą telekomunikacyjnym może być osoba wykonująca działalność gospodarczą we własnym imieniu oraz wspólnicy spółki cywilnej wykonujący taką działalność (art. 4 SwobDziałU), a także samorząd wojewódzki, który został upoważniony do prowadzenia komercyjnej działalności telekomunikacyjnej na mocy art. 13

13 Przesądza o tym treść art. 3 ust. 4 WspRozwTelU, który stanowi, że „Działalność, o której mowa w ust. 1, należy do zadań własnych o charakterze użyteczności publicznej jednostki samorządu terytorialnego".

14 Ustawa z dnia 2 lipca 2004 r. o swobodzie działalności gospodarczej, tekst jedn. Dz.U. z 2015 r., poz. 584 (dalej: SwobDziałU).

15 C. Kosikowski, Ustawa o swobodzie działalności gospodarczej. Komentarz, Warszawa 2011, s. 32-33. 
ust. 2 SamWojU ${ }^{16}$. Ponadto działalność samorządu wojewódzkiego będzie musiała spełniać dwie dodatkowe przesłanki ustanowione w art. 13 ust. 2 SamWojU. Pierwsza z nich dotyczy formy prawnej, ponieważ województwo może prowadzić działalność komercyjną jedynie w formie spółek kapitałowych. Druga przesłanka to wymóg, aby działalność gospodarcza województwa służyła jego rozwojowi.

O tym czy dany podmiot będzie uznany za przedsiębiorcę telekomunikacyjnego, decyduje także rodzaj wykonywanej działalności. Przedsiębiorcy, w rozumieniu art. 4 SwobDziałU, są uprawnieni do podejmowania działalności określonej w art. 1 ust. 1 pkt 1 PrTel. Natomiast województwo może wykonywać działalność telekomunikacyjną $\mathrm{w}$ zakresie wyznaczonym przez art. 3 ust. $1 \mathrm{WspRozwTelU.}$ Wydaje się, że zarówno przedsiębiorcy, jak i samorząd wojewódzki mogą podejmować także inne rodzaje działalności telekomunikacyjnej, jednak aby zyskać status przedsiębiorcy telekomunikacyjnego, ich działalność musi się mieścić w węższym zakresie określonym $\mathrm{w}$ art. 1 ust. 1 pkt 1 PrTel.

\section{RODZAJE STANÓW NADZWYCZAJNYCH}

Opisana tu działalność telekomunikacyjna może zostać ograniczona w przypadku wystąpienia tak zwanych stanów nadzwyczajnych, które zostały uregulowane w rozdziale XI Konstytucji RP, a także w ustawach szczególnych ${ }^{17}$. Za stan nadzwyczajny uważa się taki stan w wewnętrznym porządku państwa, w którym część obowiązujących norm konstytucyjnych zostaje zawieszona, a w ich miejsce wstępują regulacje szczegółowe ${ }^{18}$. Stan ten można wprowadzić, gdy zwykłe środki konstytucyjne są niewystarczające oraz gdy zostaną spełnione dodatkowe warunki przewidziane w odrębnych ustawach ${ }^{19}$. Ustawodawca konstytucyjny przewidział w art. 228 ust. 1 Konstytucji RP trzy rodzaje stanów nadzwyczajnych: wojenny, wyjątkowy i klęski żywiołowej.

Stan wojenny uregulowany został w art. 229 Konstytucji RP:

W razie zewnętrznego zagrożenia państwa, zbrojnej napaści na terytorium Rzeczypospolitej Polskiej lub gdy z umowy międzynarodowej wynika zobowiązanie do wspólnej obrony przeciwko agresji, Prezydent Rzeczypospolitej na wniosek Rady Ministrów może wprowadzić stan wojenny na części albo na całym terytorium państwa.

16 Ustawa z dnia 5 czerwca 1998 r. o samorządzie województwa, tekst jedn. Dz.U. z 2016, poz. 486 (dalej: SamWojU).

17 B. Banaszak, Konstytucja Rzeczypospolitej Polskiej. Komentarz, Warszawa 2012, s. 1087.

18 L. Garlicki, Polskie prawo konstytucyjne. Zarys wyktadu, Warszawa 2015, s. 386; T. Kęsoń, Stan wojny a stan wojenny - zagadnienia formalnoprawne, „Rocznik Bezpieczeństwa Międzynarodowego" 8, 2014, poz. 2, s. 149.

${ }_{19}$ K. Wojtczak, Granice ingerencji ustawodawczej w sferę praw człowieka w Konstytucji RP, Kraków 1999, s. 250 n. 
Niemal identyczna treść znajduje się w art. 2 ust. 1 ustawy z dnia 29 sierpnia 2002 r. o stanie wojennym oraz kompetencjach Naczelnego Dowódcy Sił Zbrojnych i zasadach jego podległości konstytucyjnym organom Rzeczypospolitej Polskiej $^{20}$. Jednakże w ustawie doprecyzowano przesłankę zewnętrznego zagrożenia państwa, dodając, że zagrożenie to może być spowodowane działaniami o charakterze terrorystycznym bądź działaniami w cyberprzestrzeni. Ponadto, w art. 2 ust. 1a i ust. 1b StanWojU zdefiniowano, czym jest zewnętrzne zagrożenie państwa i cyberprzestrzeń. Zgodnie z tymi przepisami, zewnętrzne zagrożenie państwa to

celowe działania, godzące w niepodległość, niepodzielność terytorium, ważny interes gospodarczy Rzeczypospolitej Polskiej lub zmierzające do uniemożliwienia albo poważnego zakłócenia normalnego funkcjonowania państwa, podejmowane przez zewnętrzne w stosunku do niej podmioty.

\section{Natomiast cyberprzestrzeń określono jako}

przestrzeń przetwarzania i wymiany informacji tworzoną przez systemy teleinformatyczne, określone w art. 3 pkt 3 ustawy z dnia 17 lutego 2005 r. o informatyzacji działalności podmiotów realizujących zadania publiczne (Dz.U. z 2014 r., poz. 1114 oraz z 2016 r., poz. 352), wraz z powiązaniami pomiędzy nimi oraz relacjami z użytkownikami.

Ważną kwestią jest także nieustanowienie ram czasowych obowiązywania stanu wojennego. Należy uznać, że jest to uzasadnione ze względu na okoliczności i przyczyny jego wprowadzenia ${ }^{21}$.

Kolejnym stanem nadzwyczajnym jest stan wyjątkowy uregulowany w art. 230 Konstytucji RP i w ustawie z dnia 21 czerwca 2002 r. o stanie wyjątkowym ${ }^{22}$. Przywołany przepis Konstytucji RP przewiduje możliwość wprowadzenia stanu wyjątkowego w przypadku zagrożenia konstytucyjnego ustroju państwa, bezpieczeństwa obywateli lub porządku publicznego. Zagrożenia te mają charakter wewnętrzny, co uznawane jest za cechę odróżniającą stan wyjątkowy od stanu wojennego ${ }^{23}$. Kompetencje do wprowadzenia stanu wyjątkowego ma prezydent, który może tego dokonać na wniosek Rady Ministrów, na czas oznaczony (nie dłuższy niż dziewięćdziesiąt dni) na terytorium całego państwa bądź na jego części. Także w tym przypadku przepisy ustawy konkretyzują postanowienia Konstytucji RP, stanowiąc, że zagrożenia uzasadniające wprowadzenie stanu wyjątkowego mogą być spowodowane działaniami o charakterze terrorystycznym lub działaniami w cyberprzestrzeni. Jednocześnie w art. 2 ust. 1a StanWyjU zdefiniowano cyberprzestrzeń w sposób identyczny jak w ustawie normującej stan wojenny. Należy tu zaznaczyć, że zakres przesłanek dopuszczających wprowadzenie

20 Tekst jedn. Dz.U. z 1 czerwca 2016 r. poz. 851 (dalej: StanWojU).

21 W. Skrzydło, Konstytucja Rzeczypospolitej Polskiej. Komentarz, Warszawa 2013, s. 304.

22 Tekst jedn. Dz.U. z 2016 r., poz. 886 (dalej: StanWyjU).

23 A. Surówka, Relacja zasad ograniczania wolności i praw człowieka i obywatela w stanach nadzwyczajnych $i$ w stanie normalnego funkcjonowania państwa, „Przegląd Prawa Konstytucyjnego" 2014, nr 4 (20), s. 133. 
stanu wyjątkowego nie został wyraźnie odróżniony od przesłanek wprowadzenia stanu wojennego, co może rodzić pewne problemy w praktyce ${ }^{24}$.

Ostatnim stanem nadzwyczajnym jest stan klęski żywiołowej, o którym stanowi art. 232 Konstytucji RP i ustawa z dnia 18 kwietnia 2002 r. o stanie klęski żywiołowej ${ }^{25}$. Zgodnie z Konstytucją RP można go wprowadzić w celu zapobieżenia skutkom katastrof naturalnych lub awarii technicznych noszących znamiona klęski żywiołowej oraz w celu ich usunięcia. Kompetencja do wprowadzenia stanu klęski żywiołowej przysługuje wyłącznie Radzie Ministrów, która może to zrobić na czas oznaczony, nie dłuższy niż trzydzieści dni, na terytorium całego państwa bądź na jego części. Istnieje także możliwość przedłużenia tego stanu pod warunkiem uzyskania zgody Sejmu. Postanowienia Konstytucji RP rozwija ustawa o stanie klęski żywiołowej, która w art. 3 definiuje, czym jest klęska żywiołowa, katastrofa naturalna, awaria techniczna czy cyberprzestrzeń.

\section{ZAKRES OGRANICZEŃ DZIAŁALNOŚCI TELEKOMUNIKACYJNEJ W STANIE WYJĄTKOWYM I STANIE WOJENNYM}

Cechą charakterystyczną wszystkich stanów nadzwyczajnych jest to, że ich wprowadzenie uprawnia do ograniczenia określonych praw i wolności człowieka i obywatela ${ }^{26}$, w tym także wolności prowadzenia działalności telekomunikacyjnej. Wspomniane ograniczenia dotyczą wolności gospodarczej27, która zgodnie $\mathrm{z}$ art. 20 Konstytucji RP jest jedną z podstaw naszego ustroju gospodarczego, to jest społecznej gospodarki rynkowej. Ograniczenie tej wolności dopuszcza art. 22 Konstytucji RP, w którym ustawodawca konstytucyjny zastrzega, że jest to możliwe tylko w formie ustawy i tylko ze względu na ważny interes publiczny. Dlatego też możliwość ograniczenia telekomunikacyjnej działalność gospodarczej została ustanowiona w poszczególnych ustawach regulujących stany nadzwyczajne. Ponadto ograniczenie tej działalności uzasadnione jest potrzebą ochrony konstytucyjnych wartości, takich jak życie i zdrowie, bezpieczeństwo i porządek publiczny, integralność terytorialna państwa i inne, co mieści się w zakresie znaczeniowym pojęcia „ważny interes publiczny”. Należy też podkreślić, że ograniczeniu może podlegać działalność ze sfery użyteczności publicznej, niebędąca typową działalnością komercyjną.

Możliwość ograniczenia działalności telekomunikacyjnej przewiduje art. 21 ust. 1 pkt 3 i 4 StanWojU, który w przypadku wprowadzenia stanu wojennego

${ }^{24}$ L. Garlicki, op. cit., s. 397.

25 Tekst jedn. Dz.U. z 2014 r., poz. 333.

26 J. Filaber, Zarzadzanie kryzysowe a prawa i wolności człowieka - wybrane uwagi, „Studia Erasmiana Wratislaviensia” 2010, z. 4, s. 258.

27 K. Eckhardt, Stan nadzwyczajny jako instytucja polskiego prawa konstytucyjnego, Przemyśl-Rzeszów 2012, s. 219. 
dopuszcza stosowanie cenzury i kontroli. Przepisy te stanowią, że w czasie stanu wojennego może być wprowadzona: a) kontrola treści korespondencji telekomunikacyjnej i rozmów telefonicznych lub sygnałów przesyłanych w sieciach telekomunikacyjnych; b) emisja sygnałów uniemożliwiających nadawanie lub odbiór przekazów dokonywanych przez urządzenia i sieci telekomunikacyjne, których treść może zwiększyć zagrożenie bezpieczeństwa lub obronności państwa. Wydaje się, że z art. 21 ust. 1 pkt 3 i 4 StanWojU można wywodzić obowiązek podmiotu prowadzącego działalność telekomunikacyjną, do współdziałania z organem stosującym wskazane ograniczenia. Współdziałanie to może polegać na umożliwieniu dostępu do infrastruktury i sieci telekomunikacyjnej w celu przeprowadzenia kontroli bądź zamontowania urządzeń uniemożliwiających nadawanie lub odbiór sygnałów telekomunikacyjnych, o ile zamontowanie takich urządzeń będzie konieczne.

Dalsze ograniczenia działalności telekomunikacyjnej przewiduje art. 21 ust. 3 StanWojU, uprawniający odpowiednie organy do zatrzymania korespondencji telekomunikacyjnej, a także do przerywania rozmów telefonicznych i transmisji sygnałów przesyłanych w sieciach telekomunikacyjnych. Zastrzega się jednak, że podjęcie tych działań jest dozwolone tylko wtedy, gdy zawartość bądź treść korespondencji, rozmów lub sygnałów, może zwiększyć zagrożenie bezpieczeństwa lub obronności państwa.

Należy podkreślić, że pojęcia „bezpieczeństwo” i „obronność”, pojawiające się $\mathrm{w}$ art. 21 ust. 1 pkt $4 \mathrm{i}$ art. 21 ust. 3 StanWojU nie zostały normatywnie zdefiniowane. W związku z tym należy przyjąć, że uprawniony organ decyduje o wprowadzeniu opisywanych ograniczeń na podstawie swojego uznania administracyjnego.

Odpowiednim organem decydującym o wprowadzeniu powyższych ograniczeń działalności telekomunikacyjnej jest wojewoda, o czym stanowi art. 21 ust. 2 StanWojU. Przepis ten umożliwia mu nakazanie organom administracji publicznej, działającym na obszarze województwa, wykonywanie czynności technicznych niezbędnych do prowadzenia cenzury lub kontroli. Oznacza to, że część zadań polegających na ograniczaniu działalności telekomunikacyjnej mogą wykonywać organy samorządu terytorialnego. Warto też wspomnieć, że zgodnie z art. 21 ust. 6 StanWojU decyzje organów ograniczające działalność telekomunikacyjną są ostateczne i podlegają zaskarżeniu bezpośrednio do sądu administracyjnego.

Podstawą wprowadzenia kolejnych ograniczeń działalności telekomunikacyjnej może być art. 24 ust. 1 pkt 2 i 5 StanWojU. Przepis ten zezwala między innymi na ograniczenie wolności działalności gospodarczej przez nakazanie okresowego zaniechania tej działalności albo ustanowienie obowiązku uzyskania zezwolenia na jej rozpoczęcie (art. 24 ust. 1 pkt 2 StanWojU). Konsekwencją wprowadzenia takiego ograniczenia będzie zmiana charakteru komercyjnej działalności telekomunikacyjnej, która przestanie być działalnością regulowaną, ponieważ do jej podjęcia nie będzie wystarczyło spełnienie odpowiednich wymogów i uzyskanie wpisu do rejestru działalności regulowanej. W tej sytuacji konieczne będzie uzy- 
skanie dodatkowego zezwolenia, które przyjmie formę decyzji administracyjnej. Trzeba też zaznaczyć, że przytoczone obostrzenia nie dotyczą działalności ze sfery użyteczności publicznej.

Drugie ograniczenie, ustanowione w art. 24 ust. 1 pkt 5 StanWojU, dotyczy zarówno komercyjnej działalności telekomunikacyjnej, jak i działalności ze sfery użyteczności publicznej. Przepis ten stanowi, że w czasie stanu wojennego dopuszczalne jest ograniczenie działalności telekomunikacyjnej polegające na nakazie wyłączenia urządzeń łączności lub zawieszeniu świadczenia usług telekomunikacyjnych. Wynika stąd, że na podstawie art. 24 ust. 1 pkt 5 StanWojU nie może być zawieszony inny rodzaj działalności telekomunikacyjnej, polegający na przykład na dostarczaniu sieci czy budowie infrastruktury telekomunikacyjnej. Ponadto przepis ten dopuszcza nakaz niezwłocznego złożenia do depozytu właściwego organu administracji rządowej radiowych urządzeń nadawczych i nadawczo-odbiorczych lub ustalenie innego sposobu ich zabezpieczenia przed wykorzystaniem w sposób zagrażający bezpieczeństwu lub obronności państwa.

Obostrzenia te mogą być zastosowane pod warunkiem wydania odpowiednich rozporządzeń przez właściwe organy. Przede wszystkim chodzi tu o rozporządzenie Prezydenta Rzeczypospolitej Polskiej wprowadzające stan wojenny, zawierające ogólne zezwolenie na ograniczenie określonych praw i wolności. Następnie konieczne będzie wydanie szczegółowych rozporządzeń dotyczących ograniczenia praw i wolności, o których mowa w art. 24 ust. 1 pkt 2 i 5 StanWojU. Odnośnie do ograniczenia wolności działalności gospodarczej będzie to rozporządzenie Rady Ministrów. Natomiast w przypadku nakazu wyłączenia urządzeń łączności lub zawieszenia świadczenia usług telekomunikacyjnych, a także nakazu złożenia do depozytu bądź innego zabezpieczenia urządzeń nadawczych i nadawczo-odbiorczych będzie to rozporządzenie ministra właściwego do spraw łączności i ministra właściwego do spraw informatyzacji, działających w porozumieniu z ministrem właściwym do spraw wewnętrznych, Ministrem Obrony Narodowej i ministrem właściwym do spraw finansów publicznych oraz po zasięgnięciu opinii Prezesa Narodowego Banku Polskiego w odniesieniu do bankowych systemów telekomunikacyjnych.

Podstawą ograniczenia działalności telekomunikacyjnej może być także art. 25 ust. 1 pkt 1 i 2 StanWojU, który przewiduje możliwość nałożenia na przedsiębiorcę dodatkowych zadań bądź ustanowienie dla przedsiębiorcy zarządu komisarycznego. Z posłużenia się tu przez ustawodawcę pojęciem „przedsiębiorca” wynika, że przedmiotowe ograniczenia dotyczą jedynie osób wykonujących we własnym imieniu działalność gospodarczą bądź wspólników spółki cywilnej, którzy tę działalność wykonują. Należy pamiętać, że wprowadzenie tych obostrzeń zależy od spełnienia pewnych przesłanek. W przypadku nałożenia na przedsiębiorcę dodatkowych zadań konieczne jest, aby ich realizacja była niezbędna do zapewnienia bezpieczeństwa lub obronności państwa oraz zaopatrzenia ludności. Z kolei wprowadzenie zarządu komisarycznego dopuszczalne jest tylko gdy dzia- 
łalność przedsiębiorcy polega na wytwarzaniu wyrobów lub świadczeniu usług o szczególnym znaczeniu dla bezpieczeństwa lub obronności państwa. Wydaje się, że działalność telekomunikacyjna spełnia te wymogi, ponieważ zapewnienie przepływu informacji może być bardzo istotne w zabezpieczeniu bezpieczeństwa lub obronności państwa (na przykład gdy zachodzi potrzeba przekazywania poufnych informacji). Ponadto zapewnienie sprawnej komunikacji między właściwymi służbami może być kluczowe w zaopatrzeniu ludności, co uzasadniałoby nałożenie na przedsiębiorcę telekomunikacyjnego dodatkowych zadań.

Ograniczenia działalności telekomunikacyjnej, o których mowa w art. 25 ust. 1 pkt 1 i 2 StanWojU, wydawane są przez organy administracji rządowej wymienione w art. 25a ust. 2 StanWojU. Przepis ten zalicza do nich: organ założycielski przedsiębiorstwa państwowego, ministra wykonującego prawa $\mathrm{z}$ tytułu posiadania akcji lub udziałów należących do skarbu państwa, właściwego terytorialnie wojewodę, a także ministrów określonych w przepisach na podstawie art. 6 ustawy o organizowaniu zadań na rzecz obronności państwa realizowanych przez przedsiębiorców ${ }^{28}$.

Niemal identyczne regulacje dotyczące ograniczenia działalności telekomunikacyjnej zawiera ustawa o stanie wyjątkowym, z wyjątkiem możliwości nałożenia na przedsiębiorcę dodatkowych zadań bądź ustanowienia dla przedsiębiorcy zarządu komisarycznego. Także tutaj, w art. 20 ust. 1 pkt 3 i 4 StanWyjU, przewidziano obostrzenia polegające na: a) kontroli treści korespondencji telekomunikacyjnej i rozmów telefonicznych lub sygnałów przesyłanych w sieciach telekomunikacyjnych i b) emisji sygnałów uniemożliwiających nadawanie lub odbiór przekazów dokonywanych przez urządzenia i sieci telekomunikacyjne. Ponadto w art. 20 ust. 3 StanWyjU ustawodawca dopuścił możliwość zatrzymania korespondencji telekomunikacyjnej, przerywania rozmów telefonicznych i transmisji sygnałów przesyłanych w sieciach telekomunikacyjnych.

Jednakże co do obostrzeń polegających na: zagłuszaniu sygnałów telekomunikacyjnych, zatrzymywaniu korespondencji, przerywaniu rozmów i sygnałów ustawodawca przewidział inne kryteria zastosowania tych ograniczeń. Zalicza do nich zagrożenie konstytucyjnego ustroju państwa, a także bezpieczeństwa obywateli lub porządku publicznego. Natomiast w ustawie regulującej stan wojenny było to zagrożenie bezpieczeństwa lub obronności państwa. Także w tym przypadku ustawa o stanie wyjątkowym nie definiuje, czym jest konstytucyjny ustrój państwa, bezpieczeństwo obywateli czy porządek publiczny, dlatego zastosowanie przywołanych ograniczeń będzie zależało od uznania administracyjnego uprawnionego organu. Organem tym, tak jak w stanie wojennym, będzie właściwy wojewoda, który może nakazać organom administracji publicznej działającym na terenie województwa wykonywanie czynności technicznych niezbędnych do prowadzenia cenzury lub kontroli (art. 20 ust. 2 StanWyjU).

28 Dz.U. poz. 1320 oraz z 2002 r., poz. 1571. 
Podobnie jak w stanie wojennym także w stanie wyjątkowym dopuszczalne są ograniczenia wolności i praw człowieka i obywatela polegające na nakazie okresowego zaniechania działalności gospodarczej albo ustanowieniu obowiązku uzyskania zezwolenia na jej rozpoczęcie (art. 21 pkt 2 StanWyjU), jak też na nakazie wyłączenia urządzeń łączności lub zawieszenia świadczenia usług telekomunikacyjnych oraz nakazie złożenia do depozytu bądź innego zabezpieczenia radiowych urządzeń nadawczych i nadawczo-odbiorczych (art. 21 pkt 6 StanWyjU). Jednakże w tym ostatnim przypadku inne zabezpieczenie urządzeń radiowych ma na celu niedopuszczenie do wykorzystania ich w sposób zagrażający konstytucyjnemu ustrojowi państwa, bezpieczeństwu obywateli albo porządkowi publicznemu. Co więcej, organem wydającym rozporządzenie dotyczące zaniechania działalności gospodarczej lub obowiązku uzyskania dodatkowego zezwolenia będzie właściwy wojewoda, pod warunkiem że stan wyjątkowy wprowadzono w jednym województwie lub jego części.

\section{WNIOSKI}

Przytoczone przepisy normujące stan wojenny i stan wyjątkowy mogą ograniczać wszystkie rodzaje działalności telekomunikacyjnej wymienione w art. 1 ust. 1 pkt 1 PrTel i art. 3 ust. 1 WspRozwTelU. Co więcej, ograniczenia te mogą dotyczyć jedynie działalności gospodarczej zdefiniowanej w art. 2 SwobDziałU albo działalności gospodarczej i działalności ze sfery użyteczności publicznej polegającej na bieżącym i nieprzerwanym zaspokajaniu zbiorowych potrzeb ludności świadczeniem usług powszechnie dostępnych. Wynika stąd, że podmiotem, którego działalność telekomunikacyjna może podlegać ograniczeniu, będzie przedsiębiorca telekomunikacyjny wykonujący działalność gospodarczą polegającą na dostarczaniu sieci telekomunikacyjnych, świadczeniu usług towarzyszących lub świadczeniu usług telekomunikacyjnych. Może to być jednostka samorządu terytorialnego prowadząca działalność telekomunikacyjną w sferze użyteczności publicznej.

Zakres tych ograniczeń zależy od uznania właściwych organów, które mogą podejmować różne środki w celu przeciwdziałania skutkom zagrożeń uzasadniających wprowadzenie przedmiotowych stanów nadzwyczajnych. Jednocześnie należy stwierdzić, że mimo zastosowania podobnych rozwiązań w ustawie regulującej stan wojenny i stan wyjątkowy istnieją pewne różnice odnośnie do dopuszczalnych środków ograniczających działalność telekomunikacyjną. Różnice te są przedmiotowe i podmiotowe. Pierwsze dotyczą możliwości zastosowania pewnych przepisów pod warunkiem wystąpienia określonych zagrożeń. W stanie wojennym będzie to zagrożenie bezpieczeństwa lub obronności państwa, a w stanie wyjątkowym zagrożenie konstytucyjnego ustroju państwa, bezpieczeństwa obywateli lub porządku publicznego. Natomiast różnica w stosowaniu opisanych 
ograniczeń o charakterze podmiotowym polega na wydawaniu rozporządzeń nakazujących okresowe zaniechanie prowadzenia działalności gospodarczej bądź obowiązek uzyskania zezwolenia na prowadzenie tej działalności przez Radę Ministrów w stanie wojennym i właściwego wojewodę w stanie wyjątkowym.

Należy też podkreślić, że w stanie wojennym można wprowadzić dodatkowe ograniczenia, polegające na możliwości nałożenia na przedsiębiorcę dodatkowych zadań bądź ustanowienia dla przedsiębiorcy zarządu komisarycznego. Takich ograniczeń nie przewiduje ustawa o stanie wyjątkowym.

\section{LIMITATION OF TELECOMMUNICATIONS ACTIVITY DURING MARTIAL LAW AND THE STATE OF EMERGENCY}

\section{Summary}

Telecommunications activity is a peculiar kind of economic activity. In specific situations, this activity might be subject to limitation. An example of such situations are the circumstances regulated in chapter XI of Polish Constitution, in which the freedom of carrying out telecommunications operations might be limited. This article consists of the description of the types of telecommunications activity and the regulations and laws governing martial law and the state of emergency which allow the limitation on telecommunications activity. 